\title{
Marital Cakes and Conscientious Promises
}

\author{
G. P. Marcar*
}

\begin{abstract}
The U.S. Supreme Court has recently been tasked with determining-both metaphorically and literally - whether in matters of marriage equality and religious freedom, those within society can have their cake and eat it too. This came to the fore in Masterpiece Cakeshop (2018). In most of scholarship which has followed, the respective parties'rights in this case are parsed in terms of rights to religious expression and free speech (on the one hand), and a statutory right to non-discrimination (on the other). By approaching this matter through a primarily philosophical (rather than legal) lens, I aim to present a new perspective. Where cases involve same-sex marriage, it is argued that both sides are predicated upon religious or conscientious convictions. This is established through a philosophical argument, which examines the nature of the marital promise to love and seeks to demonstrate how this promise entails a characteristically religious sort of belief.
\end{abstract}

\section{KEYWORDS}

Masterpiece Cakeshop, Religious Freedom, Marital Love Promises, Conscientious Beliefs, Moral Anthropology

\section{CONTENTS}

I. Introduction: Masterpiece CAKeshop AND the Importance of RELIGIOUS FREEDOM 202

A.The Discrimination Claim: A Question of Cakes ......................... 202

B.Justice Gorsuch and the Importance of Religious Freedom ........ 203

C. Different Cakes, Different Unions? Obergefell Revisited ........... 204

II. The Marital Promise to Love Another as an Exercise of Religious

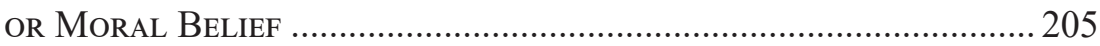

A. The Promise to Love Another ................................................... 206

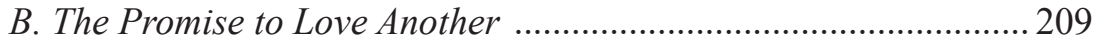

C. The Promise to Love Another, Forever: An Intrinsically Religious Promise? 213

III. CONCLUSION

* G. P. Marcar is the Harold Turner Research Fellow at the Centre for Theology and Public Issues, University of Otago. He would like to thank the International Centre for Law and Religion Studies (BYU law), whose 2019 Fellowship program at Christ Church, Oxford was the genesis for this article. 


\section{Introduction: Masterpiece CAKESHOP AND THE IMPORTANCE OF RELIGIOUS FREEDOM}

In 2012, Charlie Craig and David Mullins were denied service by Jack Phillips of Masterpiece Cakeshop in Colorado. Mr. Craig and Mr. Mullins sought a cake (without specifying any particularised writing or decoration) in order to celebrate the advent of their lawful marriage in Massachusetts. The issue was heard by the Colorado Civil Rights Commission ("the Commission"). ${ }^{1}$ The Commission held that in refusing the couple's order, Phillips had violated the Colorado AntiDiscrimination Act of 2014 ("CADA"), which prohibits any "place of business engaged in any sales to the public" from directly or indirectly discriminating against persons because of their sexual orientation. Against this, Phillips argued that having to make a cake to celebrate the same-sex couple's marriage would violate his rights to freedom of expression and religious exercise under the U.S. Constitution's First Amendment. It is along the lines of these contours - the right to non-discrimination, on the one hand, versus the right to freedom of expression and religious exercise, on the other- that scholars have since sought to adjudicate this case. ${ }^{2}$

\section{A.The Discrimination Claim: A Question of CaKes}

Although the Court's opinion refrained from balancing the parties' rights in Masterpiece, ${ }^{3}$ Justice Gorsuch's concurrence offered an assessment. For the purposes of this article, Justice Gorsuch's opinion is particularly interesting in two respects: firstly, because it frames the other rights in terms of what the baked good being offered to the couple is taken to be; secondly, for its insistence that $\mathrm{Mr}$. Phillips' religious beliefs should be determinative in this matter.

To begin with the first of these aspects, Gorsuch notes how the level of specificity attached to the cake impacts the validity of claims being made. He thus accuses the Court of applying "a sort of Goldilocks rule," whereby "describing the cake by its ingredients is too general; understanding it as celebrating a same-sex wedding is too specific; but regarding it as a generic wedding cake is just right." ${ }^{4}$ One area in which this exercise in cake calibration impacts the parties' rights and interests most clearly concerns the couples' claim to have been discriminated against on the basis of their sexuality, contrary to CADA. In refusing to sell them a marriage cake, it was alleged that insofar as this baker would have happily sold any betrothed heterosexual couples the same product, he had clearly discriminated against the couple because they were homosexual. Against this claim, Mr. Phillips insisted that he was not discriminating against these specific customers: he would

Craig v. Masterpiece Cakeshop, 370 P.3d 272 (Colo. App. 2015).

See, e.g., Anton Sorkin, A Starch Reality: What Is at Stake in Masterpiece Cakeshop?, 7 Oxf. J. Law Relig. 153, 153-59 (2018); Edward J. Schoen, Masterpiece Cakeshop: A Case Study Brought to You by the U.S. Supreme Court, 29 South. Law J. 25 (2019).

3 For a sample of scholarly disappointment this has attracted, see for instance Chad Flanders and Sean Oliveira, An Incomplete Masterpiece, 66 UCLA L. Rev. 156-74 (2019); Mark Strasser, Masterpiece of Misdirection, 76 WASH. \& LEE L. Rev. 963-1012 (2019).

4 Masterpiece Cakeshop, Ltd. v. Colorado Civil Rights Comm'n, 138 S. Ct. 1719, 1738 (2018). 
not have sold a "same-sex marriage cake" to any person, regardless of his/her sexuality.

The validity of the discrimination claim is thus predicated upon the nature of the cake. If it is conceived as a (generic) "marriage cake," then the baker would have been discriminating against the same-sex couple, as he would not have been denied this product to a heterosexual couple. If, however, the cake in question is a "same-sex marriage cake," as Mr. Phillips appears to have held, then the baker may legitimately claim that he did not discriminate against the couple. As will be discussed further below, for Justice Gorsuch, how the cake should be defined is not simply a matter of perspective, but of (Mr. Phillip's) religious perspective.

\section{B.JUSTICE GoRSUCH AND THE IMPORTANCE OF RELIGIOUS FREEDoM}

The success of the couple's discrimination claim in Masterpiece is thus predicated upon the nature of the product. Who or what should decide this question? For Justice Gorsuch, it is the prerogative of the religious person (in this case, Mr. Phillips) to determine upon the item's socio-religious significance or meaning. This, Gorsuch argues, holds irrespective of whether the cake had any distinctive words or symbols. 5 Akin to an "emblem" or a "flag", a same-sex wedding cake is a symbol which conveys agreement with a particular set of beliefs or institutions. ${ }^{6}$ Forcing someone to create such a symbol therefore implicates religious faith to just the same extent as written words. "To some, all wedding cakes may appear indistinguishable. But to

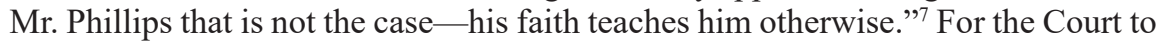
suggest that a gay-marriage wedding be regarded by all parties as just a "wedding cake" is akin, Gorsuch suggests, to saying that "sacramental bread is just bread or a kippah is just a cap." " The dictates of Mr. Phillips' faith meant that he viewed the requested baked good as not just a wedding cake but as a same-sex wedding cake, endowed with religious significance and therefore violative of his freedom (under the First Amendment's Free Exercise Clause) to produce. ${ }^{9}$

In order to further illuminate Justice Gorsuch's thought concerning the prerogative of religious believers to determine the terms and meaning of debate, it will be instructive to briefly turn to his prior rulings on the Federal Court of Appeal's $10^{\text {th }}$ Circuit. In Hobby Lobby, Justice Gorsuch argued that as a result of the right to free exercise of religion being violated, both the company (Hobby Lobby) and their owners, the Greens, should be entitled to financial relief. In a highly telling paragraph, Gorsuch states that:

All of us must answer for ourselves whether and to what degree we are willing to be involved in the wrongdoing of others. For some, religion

\footnotetext{
Id.

6 Id. (citing West Virginia Bd. of Educ. v. Barnette, 319 U.S. 624, 632, 63 S. Ct. 1178, 87

L. Ed. 1628 (1943).).

Id. at 1739 .

Id. at 1740 .

9 See also the UK Supreme Court's judgment in Ashers Bakery that making the baker in that case produce a cake for a same-sex couple would have been "akin to a Christian printing business being required to print leaflets promoting an atheist message." Lee $\mathrm{v}$ Ashers Baking Co. Ltd, [2018] UKSC 49, [2020] AC 413 (Appeal taken from N. Ir.).
} 
provides an essential source of guidance both about what constitutes wrongful conduct and the degree to which those who assist others in committing wrongful conduct themselves bear moral culpability. ${ }^{10}$

Gorsuch here draws upon the previous case of Thomas v. Review Board of the Indiana Employment Security Division (1981) in order to illustrate his point that it is a matter for religious believers to determine when a state of affairs is intolerable to their faith. In Thomas, the plaintiff, a Jehovah's Witness, was willing to participate in manufacturing sheet steels he knew might be used in armaments, but was unwilling to work on a fabrication line producing tank turrets. ${ }^{11}$ Following the plaintiff's success in this case, Gorsuch argues that no one should have to forsake her religious beliefs in order to participate in the public sphere, and it is up to the religious person alone to say where the line is. To briefly reconnect this reasoning back to Masterpiece, it will be recalled that the discrimination claim against the baker in this case stands or falls upon whether the cake in question is a "marriage cake" or "same-sex marriage cake". According to Gorsuch's position, this question is one which the party exercising religious beliefs (Mr. Phillips) should decide.

Mr. Phillip's religious position that marriage cakes and same-sex marriage cakes are ontologically and qualitatively distinct, it might be further observed, entails an antecedent judgement that the unions connected with these cakes are also fundamentally different. Same-sex marriage, on this view, is a different kind of thing from heterosexual marriage. The cake to celebrate the former is therefore properly regarded as a "same-sex marriage cake," rather than a "marriage cake" for same-sex people.

This raises the question of how the Court has construed the nature of same-sex marriage.

\section{Different Cakes, Different Unions? Obergefell ReVISITED}

As Jeremy Waldron points out, marriage may be regarded a social "institution," "practice" or "reality," to which the family law of a country provides "housing." 12 Within the context of the U.S. (and much to Waldron and others' disagreement), this legal housing was provided not by a congressional statute, but instead by the Court's determinations - around three years after the events which culminated in Masterpiece Cakeshop -in Obergefell v. Hodges (2015).

In Obergefell, the Court passed a landmark ruling that same-sex couples had a constitutional right to marriage under the "Due Process" and "Equal Protection" clauses of the Fourteenth Amendment. ${ }^{13}$ Drawing upon its previous case law from

$10 \quad$ Hobby Lobby Stores, Inc. v. Sebelius, 723 F.3d 1114, 1152 (10th Cir. 2013). See also Gorsuch's 10th Circuit opinion in Yellowbear v. Lampert, 741 F. 3d 48 (2014).

11 Thomas v. Review Bd. of the Indiana Emp't Security Div., 450 U.S. 707 (1981).

12 Jeremy Waldron, What a Dissenting Opinion Should Have Said in Obergefell v. Hodges, N.Y.U. SCHOOL OF LAW, PUBLIC LAW RESEARCH PAPER NO. 16-44 (2016).

13 Admittedly, this case was not decided at the time of the events surrounding Masterpiece Cakeshop, which meant that the Mr. Phillips could claim that a substantial legal difference pertained between same-sex and opposite-sex couples seeking wedding cakes (same-sex marriage was not legal in Colorado at the time). Such an argument, however, would not now be available to him or any other baker in a similar situation in the United States. 
Loving v. Virginia (which invalidated bans on interracial unions) and Turner v. Safley (which held that prisoners could not be denied the right to marry), the Court classed marriage among the "fundamental liberties protected by the Fourteenth Amendment's Due Process Clause," crucially among which are "certain personal choices central to individual dignity and autonomy, including intimate choices defining personal identity and beliefs." ${ }^{14}$ Comparing the union of same-sex couples with that of their opposite-sex counterparts, the Court asserts that since "marriage is a keystone of the Nation's social order," it is therefore "demeaning to lock same-sex couples out...for they too may aspire to the transcendent purposes of marriage."15 The Court did not elaborate much on the "transcendent purposes" of same-sex marriage. However, its subsequent assertions strongly depict marriage in terms of an exclusive relationship between two people, in which a life-long commitment is made, and a joint identity formed, which transcends the sum of its parts. The Court stated that:

No union is more profound than marriage, for it embodies the highest ideals of love, fidelity, devotion, sacrifice, and family. In forming a marital union, two people become something greater than once they were...marriage embodies a love that may endure even past death. ${ }^{16}$

In Obergefell, the Court thereby put forward a positive vision for the potentiality of same-sex marriage to be a self-transcending union of two people in a faithlike commitment of love to one another. Within this vision, it may be observed that many same-sex marriages possess a commonality with many opposite-sex marriages, insofar as both centre upon the absolute promise of two people to love one another for the remainder of their lives ("the marital promise"). The remainder of this article will argue that the marital promise to love another should itself be viewed as an exercise of religious or conscientious freedom.

\section{The Marital Promise to Love Another as an Exercise OF RELIGIOUS OR MORAL BELIEF}

In what follows, I will argue that the marital promise to love another should be considered an exercise of religious or moral belief. At first glance, this claim may seem highly questionable. For one, it is not immediately obvious that "beliefs" are a constitutive part of "promises" at all. In order to address this issue-which necessarily precedes any analysis concerning whether it can be characterised as a "religious" belief - the lens of philosophy must be utilised.

Through this lens, the observations which follow in this section are twofold. Firstly, it will be suggested that there is something proto-religious about the practice of making promises itself, and that this proto-religiosity is particularly acute in the case of the marital promise. Promises, qua promises, ultimately concern the moral beliefs and normative intentions of the participants, and as such are not reducible

14 Obergefell v. Hodges, 135 S. Ct. 2071, 2587 (2015). See also Loving v. Virginia, 388 U.S. 1 (1967); Turner v. Safley, 482 U.S. 78 (1987).

15 Obergefell v. Hodges, 135 S. Ct. 2071, 2590 (2015).

$16 \quad$ Id. at 2608. 
to either naturalistic or positivistic accounts. Secondly, it will be argued that when the object of one's promise is perpetual love for another person, the rationality and moral responsibility of this particular promise (qua alleged "promise against the evidence") assumes anthropological assumptions and moral commitments on the part of the parties involved.

\section{A. The Promise to Love Another}

To begin, it may be argued promises, by their very nature, escape objective and non-moral explanation. Much work has recently been done within philosophy on the nature of promissory obligation. Following David Hume's lead, ${ }^{17}$ however, Catholic moral philosopher Elizabeth Anscombe uniquely suggests that a prior and more fundamental problem should first be addressed. What it means to be "making a promise," Anscombe holds, is not itself something which is capable of intelligibility under a naturalistic framework. ${ }^{18}$ Promises, Anscombe points out, belong to a particular class of verb. Promises are institutional verbs, in that that their meaning cannot be separated from the beliefs and intentions of those engaged in them. A person is only making a promise if that is what they understand themselves to be doing. In other words, " $\mathrm{x}$ is promising" is only the case if $\mathrm{x}$ believes that he/ she is engaged in an exercise of promise-making. A vicious circularity ensues, as Anscombe explains:

If thinking you are getting married is essential to getting married, then mention of thinking you are getting married belongs in an explanation of what getting married is; but then won't an explanation of what getting married is be required if we are to give the content of thought that one is getting married? Hence it will be impossible to explain what getting married is and impossible to say what is the thought of the man who thinks he is getting married. ${ }^{19}$

This is the paradox of promising. The action of "getting married" (making a marital promise) is explained with reference to expressing the thought that you are getting married, but such a thought requires a prior understanding of what getting married is. The thought of getting married simultaneously constitutes the explanation of what it is make a marital promise-indeed, Anscombe stresses that it is both an "indispensable verifier" and precondition of making this promise - and requires one. ${ }^{20}$ Anscombe further illustrates this point with a situation wherein all the physical or external conditions are present for making a marital promise, including two parties who say the appropriate promissory words, but one of these parties

17 See David Hume, A Treatise on Human Nature 477-570 (L. A. Selby-Bigge ed., Clarendon Press 1888) (1739).

18 G. E. M. Anscombe, On Promising and Its Justice, and Whether It Need be Respected in Foro Interno, 3 CRítica: Revista Hispanoamericana De Filosofía, May, 1969, at 61; G. E. M. Anscombe, Rules, Rights, and Promises, 3 Midwest Stud. IN Phil. 318 (1978).

19 Anscombe, On Promising and Its Justice, supra note 18.

$20 \quad$ Id. at 62. 
believes that they are participating in a rehearsal, rather than an actual ceremony. ${ }^{21}$ In such a case, even though the correct external action is being performed (and the parties involved believe that the action would be sufficient, if their intention was present), no promise would actually occur because the belief that a promise was being made was absent.

At first sight, this aspect of promises seems to render the concept intrinsically problematic. Anscombe likens the bringing forth of a promise through the parties' belief about their situation and the significance of their words to "someone's having substantive existence because someone loved him." 22 Such a scenario, however, "seems impossible. Whom did the lover love, if he was not in a state of illusion?"23 While thought or belief may be the efficient cause of something coming into existence (as in any personal plan), it nevertheless remains the case, for the sake of objective coherence, the thing which thereby comes into existence must be capable of having a description (and thus of being describable) independently from the fact that it has been thought, believed or desired. ${ }^{24}$ No such independent descriptive account, however, appears available when it comes to promises.

Once again following Hume's lead, Anscombe argues that the solution to this quandary is in viewing the practice of making a promise as part of a social-linguistic game. In order to "make a move" in this "language game" (in the Wittgensteinian sense of the term), one needs to be acting as a player in the game, in accordance with its rules. This, Anscombe writes, "involves that you are acquainted with the game and have an appropriate background, and also appropriate expectations and calculations in connection with e.g. moving this piece from point A to point B." ${ }^{25}$ This shifts the centre of discussion from what is being explicitly thought and believed about what is being done, to the act and itself and its social context. Consequently, "[i]f someone seriously thought he was only rehearsing, he would not afterwards act as if he thought he was married: if he did so, his plea that he 'thought it was only a rehearsal' would not be heard."26 This marks the beginning of a perspective, which until recently has been almost unchallenged within the philosophy of promises, of regarding the meaning of this concept as the product of social norms, conventions or institutions.

This positivist or conventionalist explanation of promises, however, is not without its own problems. ${ }^{27}$ The first objection which has often been raised against the paradigm in recent times is that it cannot explain the particularity which accompanies breaking one's promise to a specific person. When a promise is broken or unfulfilled, it is pointed out, the party with a legitimate grievance is the particular recipient of the promise, and not the larger socio-linguistic community of fellow "promise-game players." To further press the point, this objection would seem to be particularly acute in the case of that most intimate and personal of promise which is the marital promise to love another in perpetuity. When the promise to faithfully

\footnotetext{
$I d$.

Id. at 66. Id. at 66 .

Id.

$I d$.

Id. at 72 (emphasis original).

Id.

27 For a prominent example of an alternative account of promises, see Thomas Scanlon, Promises and Practices, 19 Phil. Public Aff. 199 (1990).
} 
and loyally love another in marriage is broken, it is not the community at large which has a moral claim against the partner who has strayed; it is the other marital partner.

Another objection raised to this account is that while regarding promises as a social practice or convention may rescue the concept from the conceptual and definitional difficulty which Anscombe identified with naturalistic accounts, it does not necessarily explain how or why promises should be considered as a normative exercise. One may still ask why the game of promises should be considered a good one to abide by. Anscombe's approach to this issue is to posit that the sort of modals which attach to the keeping of promises are the sort of obligations which are commonly entailed by the rules of a game: the player "has to" play in a certain way (which Anscombe terms "stopping modals") and "cannot" act in contravention of the rules ("forcing modals"), as to do otherwise would be contrary to the norms and expectations of others. In response, however, it might be objected that this is not the sort of expectational belief held by those who understand themselves to be making or receiving a promise-perhaps particularly in the case of a commitment to love another in marriage.

As Michael Pratt observes, the sort of expectation and belief held by those who in a promise-making situation is a normative one. The expectation of the promisee is not based on a descriptive prediction that the promisor will do what they have committed to, but on a moral expectation that the promisor regards it as normatively wrong not to fulfil his promises ${ }^{28}$ Moreover, on Pratt's view, a promise can only be said to be made where the speaker communicates an intention to be morally (as opposed to merely socially or legally) bound by the promise); indeed, Pratt observes that this is what separates promises from merely civil and legal contracts. ${ }^{29}$ It may therefore be argued that while the conventionalist account of promises evade the objection which Anscombe formulates that the concept of promises, qua institutional verb, is naturally unintelligible, it is still subject to a second critique: that no account can be given (either naturalistically or in terms of socio-linguistic agreement) of how the making of a promise can entail a moral obligation. This seems especially pertinent in the case of the marital promise to love another, due to the particular gravity and import of this particular promise. Frequently, the promises which one makes - though still entailing a moral responsibility - are not existentially significant. In promising to love another person for the rest of his/her life, a person makes a promise whose consequences and implications (both for him/ herself and for the other person involved) arguably exceed those of any other, such as to make the moral obligation involved in the marital promise particularly heavy.

Consequently, the marital promise, qua promise, evades either naturalistic or conventionalist explanation: it must instead be considered a form of moral belief. I will now explore how further examination of how the rationality and responsibleness of the marital promise, qua promise to love another, involves subscription to specific framework of moral, anthropological and metaphysical beliefs.

\footnotetext{
28 See Michael Pratt, Promises and Perlocutions, 5 Critical Rev. Int'L Soc. Pol. Phil. 93 (2010). .

29 See Michael Pratt, Contract: Not Promise, 35 Fla. St. U. L. Rev. 801, 812 (2008).
} 


\section{B. The Promise to Love ANother}

The promise of two betrothed parties, qua unconditional promise to love, has been the subject of many recent philosophical discussions and critiques. As will be seen, these can be divided along broadly the same lines as were visible with promises in general. That is to say, the same problems raised concerning promises in general can be seen to re-emerge with promises to love, albeit in a different form.

For one, it is argued that while actions may be under the control of the will — and thus appropriate things to promise - affections (such as love or happiness) are not. As Elizabeth Brake puts it, "the very concept of love may include uncontrollability, because it involves attitudes of respect or admiration or care or desire, which by their nature, cannot be forced....even by oneself." 30 Insofar as promising something involves making a prediction, one cannot promise something which is by nature unpredictable.

The assertion that promises can only be made concerning things within one's control can be pressed even further. Love would seem dependent upon many of the contingencies which are constitutive of human life. These include one's own character, as well as that of the other person. ${ }^{31}$ While a conditional promise to love might therefore be appropriate, an unconditional promise should not be made, due to the contingent and transient nature of love's many variables, including personal identity. Related to this is an epistemic objection: one should not promise to carry out $\mathrm{x}$ where the conditions which dictate the possibility or impossibility of x's fulfilment cannot be known in advance. One should not promise that one will be alive in 30 years' time, let alone that one will unconditionally continue to be in a relation of love with another. As Iddo Landau puts it, "[t]o promise that one's love will not end is to make a promise one may not be able to keep, about what may well be beyond one's control." ${ }^{32}$ In making a promise to love, one cannot rule out the possibility of being fundamentally mistaken about a crucial aspect of one's love, such as the character of the other person. In promising to love another person unconditionally, a person therefore fundamentally errs.

One attempt which seeks to circumvent these problems has been to argue that the marital promise to love another is not a prediction, but rather a statement of intention or desire. As John Wilson observes, in making the marital promise, the bride does not simply want to be assured that the groom believes that it (objectively speaking) is likely that he will continue to love her in the immediate future. Rather, "She wants to know whether the bridegroom intends or wants that state of affairs to continue." ${ }^{33}$ In 'Marital Faithfulness', political philosopher Susan Mendus further develops this line of thought. The marriage commitment, Mendus argues, is "more like a statement of intention" than a prediction about future actions..$^{34}$ To say that " $x$ is unconditionally committed in love to $y$ " is not to make a prediction about their

30 Elizabeth Brake, Is Divorce Promise-Breaking?, 14 Ethical Theory and Moral Practice 31 (2011).

31 See also Dan Moller, The Marriage Commitment-Reply to Landau, 80 PнiL. 279, 281 (2005).

32 Iddo Landau, An Argument for Marriage, 79 Phil. 475, 475 (2004). See also Dan Moller, An Argument Against Marriage, 78 PHIL. 79, 85 (2003).

33 John Wilson, Can One Promise to Love Another?, 64 PHIL. 557, 560 (1989).

34 Susan Mendus, Marital Faithfulness, 59 PHIL. 243, 247 (1984). 
future relationship, but rather to say that in the present moment, $\mathrm{x}$ is unconditionally committed (in x's intention) to y. Drawing upon the work of Norman Malcolm, Mendus remarks that it represents a "strong" rather than weak epistemic belief, in that in making this promise, "I cannot now envisage anything happening such as would make me give up that commitment." ${ }^{35}$ The marital promise to love one another, on this interpretation, is the assertion that one intends and desires to love another person in perpetuity.

In 'The Promise that Love Will Last', Camilla Kronqvist similarly argues that making marital promises to indefinitely love another is equivalent to neither predicting what one will do, nor predicting what one will feel. Rather, she says, "I am expressing my trust in you and my willingness that our relationship continues." ${ }^{36}$ On this view, the promise to love made in marriage concerns two primary components: belief (in the character of the other person) and intention or desire that the relationship continues to be loving. In making this argument, Kronqvist explicitly draws upon the language of belief, making a distinction between "attempts to control the indeterminacy of life and embracing it with faith in one another." ${ }^{37}$ On this view, the central elements of the promise to love are intentionality or desire, and belief or trust. Some conceptual housekeeping may be useful here. While both Kronqvist and Mendus mention intentionality, desire and belief as separate components of the marital promise to love, it is often argued within the field of philosophy of mind that intention implies both desire and belief. ${ }^{38}$ In other words, where an intention to indefinitely love another exists, both the desire to do this and belief that it is possible will be present too. It is therefore perhaps sufficient to say that the unconditional promise to love another person in marriage expresses an intention with regard to this love, rather than a prediction as to the circumstances which may befall the happy couple in the future.

Perceiving the marital promise to love another in terms of a volitional intentionality to continue loving, ${ }^{39}$ rather than a cognitive prediction concerning the future, substantially changes the framing of philosophical objections to this promise. While a significant degree of objective uncertainty fatally undermines the capacity to make a prediction, the same does not hold for intentions. As such, the arguments of thinkers such as Kronqvist and Mendus greatly helps the coherence of promising to love another. This turn to intentionality does not, however, entirely save the marital promise from its critics. In addition to a psychological state of intentionality, a promise is also a normative state. In making a promise, one imposes an obligation or injunction on oneself to do (or be) as promised. As Brake writes, "promises are not merely statements of intention. Promises create obligations, and...a stated intention to perform something impossible cannot create an obligation. ${ }^{\prime 40}$ Consideration of the morally-binding nature of a promise

\footnotetext{
Id. See Norman Malcolm, On Knowledge and Belief, 14 AnALYsis 94 (1953).

Camilla Kronqvist, The Promise That Love Will Last, 54 InQ. 650, 653 (2011).

$I d$. at 651 .

38 See, e.g., Robert Audi, Intending, 70 J. PhiL. 387 (1973); Donald Davidson, Intending, in Philosophy of History \& ACTION 41-60 (Yirmiahu Yovel ed., 1978).

39 For an interesting argument that intention of thought should be conceived as different from intentionality of desire, see P. T. Geach, Two Kinds of Intentionality?, 59 THE Monist 306-20 (1976).

40 Brake, supra note 30 , at 35.
} 
resurrects the conceptual objections noted above: there can be "no ought without a can," as Immanuel Kant famously argued. In making a promise, a person imposes an obligation upon oneself, in the form of an injunction not to break the promise. If the obligation concerns something which is by nature beyond the promisor's control-or similarly where he cannot know whether it is possible to fulfil the obligation he has made - then such a promise cannot be rationally made. Seen thus, the promise to unconditionally love another would seem to be the quintessential example of just an irrational undertaking.

Indeed, the marital promise to love another would seem to perfectly exemplify a promise which is "against the evidence." In "Promising to Try," Jason D'Cruz and Justin Kalef argue that such a promise, if made in an unqualified way, is irresponsible. Instead, D'Cruz and Kalef argue that a more conscientious choice to make would be to promise to try. ${ }^{41}$ Rather than being indicative of "bad faith, faulty reasoning, or dishonesty," the authors note that "[i]t is part of being a human being to have a limited supply of willpower" and "[i]n some cases promising to try just means being honest about this fact." ${ }^{\prime 2}$ It is not necessarily the case that the promisor in this situation lacks commitment (either to the other person or to their promise), but only that they are conscious of the possibility of failure. Conditions of failure (particularly, one might argue, over the course of one's potential lifespan) are often difficult to precisely enumerate, as a result of which the conscientious and responsible promisor will not, on this view, make an unconditioned or absolute promise, the proverbial equivalent of which is writing a cheque one cannot necessarily cash.

In response to this perspective, Berislav Marušić begins by arguing (in common with Kronqvist, Mendus and others) that promises are not a matter of weighing probabilities. Rather, promises are a matter of practical reason; they are a decision, rather than a calculation. "When considering matters that are up to us, we should look to our practical reasons, not to our evidence alone...we should decide what to do, not predict what we will do."43 Marušić gives the example of two lovers facing imminent physical separation because one of them is departing for military service. For the party who will remain in civilian life, to promise to "try" to be faithful would clearly be an inadequate response. ${ }^{44}$ Marušić quips that "[t]o echo Sartre... the lover who promises to try to be faithful is a bastard or a coward." ${ }^{45}$ As exercises of practical (rather than speculative) reason, the making and execution of promises concerns the moral character of the promisor.

This leaves open the question of whether the promise to love can be sincere or morally responsible. On this point, Marušić makes an interesting case. In apparent agreement with those who argue that the marital promise to love is untenable, Marušić holds that if one does believe that there is a "significant chance" that one will not do something, then it is indeed irrational, irresponsible or insincere to promise the contrary. ${ }^{46}$ Despite this, Marušić claims that, contrary to the objection

\footnotetext{
Jason D’Cruz \& Justin Kalef, Promising to Try, 125 Eтнісs 797, 799 (2015).

Id. at 802 .

Berislav Maruši, Promising Against the Evidence, 123 Eтнісs 292, 294 (2013).

Id. at 296.

45 Berislav Marušić, What's Wrong with Promising to Try?, 98 PAC. PHIL. Q. 249, 251 (2017) (emphasis added).

46 Maruši, supra note 43, at 304.
} 
noted above, promises to love can be sincere and rational. The reason for this, Marušić explains, is that agents may take a different view of their actions from third parties, even where everyone has access to the same evidence. While others may perceive an action which is amoral (at best) or immoral (at worst), therefore, the promisor can nevertheless be morally justified in making her promise to love because it is rational, responsible and sincere on the terms of her own perspective.

To review, the argument here turns on two claims. Firstly, it is claimed that promises (including those to love) are an exercise of practical reason rather than a prediction or calculation per se. This provides a response to the accusation that making a promise to love is irrational. Secondly, it is claimed that the coherence of deliberately and intentionally making one's love for another the object of a promissory obligation depends upon the perspective of the promisor. This provides a response to those might allege that making a promise to permanently love another person is either irresponsible or insincere, due to the fact that one cannot (rationally, as well as in good faith) make an obligation where the conditions for fulfilling the obligation are outside one's control.

Marušić's argument opens the question of what, exactly must be believed by the promisor in order for his promise to forever love another to be internally justified; that is to say, for the promise to be responsible and sincere according to the promisor's own point of view. In other words: what must be believed for one's love towards another to not necessarily (or most probably) be contingent and temporary?

Firstly, one has to believe that both oneself and the other to whom he/she is engaged will not necessarily change in a significant way so as to effectively become a different person in a few decades' time. A person's character will, of course, change over the years, but one must believe that it will not change so radically that the identity to whom one is married is no longer the individual to whom one made a promise to perpetually love. Secondly, one must believe that human beings in general (and oneself in particular) are capable under normal conditions of exercising enough freewill over their beliefs, desires and dispositions that the question of whether one will continue to love the other is not wholly outside of one's control. Thirdly and perhaps most significantly, one must believe that human beings are capable of an altruistic concern for another person which transcends one's temporal interests and desires. Moreover, not only must one believe in this moral anthropology; one must also believe that he/she does indeed have such an altruistic and transcendent concern for another human being and that this is the reason why she is making an existentially significant marital commitment.

If one subscribes to these beliefs, then one may be able to affirm (with Marušić) that the promisors' promise to love another (from their perspective) is capable of being sincere, rational and responsible. Without these beliefs, however, it is arguably difficult to see how the objections raised concerning absolute promises to love by Landau, D'Cruz and Kalef can be rebutted. In this way, it may be argued that the promise commonly made by two people to unconditionally love another in marriage necessarily implies a commitment to a particular set of non-empirical, normative beliefs which concern the humanity's metaphysical and meta-ethical landscape, as well as its moral anthropology. 


\section{The Promise to Love ANother, Forever: An INTRINSICALLY RELIGIOUS PROMISE?}

The forgoing argument stipulates that constitutive of the marital promise to love another person are beliefs. As an institutional verb, whose very definition includes that one believes that he/she is doing it, promises cannot be reduced to a naturalistic account (Anscombe). Additionally, because they are believed to impart a moral obligation, promises are also not reducible to a purely conventionalist or sociolinguistic account. With regard to marital promises to love specifically, particular moral, metaphysical and anthropological assumptions must be supposed in order for these promises not to be irrational, insincere or morally irresponsible.

The promises which some people make - as part of their marriage ceremonyto love another are both normative and permanent; that is to say, the marital promise entails an obligation on the promisors to love the other for at least the remainder of their lives. ${ }^{47}$ It is this normative longevity, it has been noted, which separates these promises from other contractual undertakings, as well as presenting a substantial obstacle to those who wish to recast the essence of the marital promise in terms of prediction, intent or desire. It is also, I submit, where the religiosity of the marital promise is perhaps most readily apparent. In Promises, Oaths, and Vows: On the Psychology of Promising, Henry J. Schlesinger observes that in its sincerity and intention to bring about a permanent state, "the marriage vow is unique." 48 Whereas "ordinary secular promises change our relationship to someone else (or to the self) temporarily" and "mark a particular intention as serious but also, perhaps implicitly, state the means of releasing us from the obligation undertaken," the promise made by prospective spouses to love one another admits to no such temporal expiration. ${ }^{49}$

As the Court in Obergefell opined, it is possible that marriage (of either the opposite-sex or same-sex variety) "embodies a love that may endure even past death." ${ }^{50}$ In promising to love someone for the rest of his/her life, a person voluntarily, consciously and intentionally puts him/herself in a permanent ethical and normative relation to one other person-in contradistinction to all others. Insofar as this promise is to an unconditioned and perpetual commitment of love, the moral obligation it entails is also absolute. To borrow the terminology of theologian Paul Tillich, ${ }^{51}$ whose conception of God and religion was referenced by the Court in United States v. Seeger, ${ }^{52}$ to make an absolute promise to love another

47 Certainly, not all legal marriages involve the making of such promises; many oppositesex and same-sex couples choose to structure their relationship differently. It remains to be determined whether the argument would be applicable to the couple in Masterpiece Cakeshop, or any other case which has so far been heard by the Court. Making a public resolution or pledge to love one another remains, however, a central feature of many marriages.

48 Herbert J. Schlesinger, Promises, OAths, and Vows: On the Psychology of PROMISING 19 (2008).

$49 \quad I d$

$50 \quad$ Obergefell v. Hodges, 135 S. Ct. 2071, 2608 (2015).

51 See Paul Tillich, The Shaking of the Foundations (2012).

52 See United States v. Seeger, 380 U.S. 163, 180 and 187 (1965). The Court in Seeger ruled that a defendant had the right to abstain from compulsory military service because of his deeply held conscientious beliefs against killing human beings. See also Torcaso v. Watkins, 367 U.S. 488 (1961) (affirming "Secular Culture" and "Ethical Humanism" 
is to engender an obligation such that its fulfillment now functions as an "ultimate concern" for the promisors. ${ }^{53}$

The marital promise is central to the promisor's self-identity, as well as defining their social and moral landscape. Due to the intentional and imperative form of the promise being made, as well as its subject being love, I have argued that marital promises entail normative beliefs which touch upon fundamental questions concerning the human condition. In intentionally placing an obligation on oneself to love someone else, an encounter with the other qua other is facilitated. Attention to the promisor's resolution to unconditionally love another without temporal limit, I now further argue, strengthens and illuminates the contention that when two people - regardless of their respective genders - seek to make a public and unconditional promise of love to one another, they are exercising a form of (broadly defined) religious freedom. Even if the participants in a marriage ceremony do not subscribe to a conventional or institutional form of religious belonging, their act of getting married may thus be regarded as endowed with religious or conscientious significance.

\section{CONCLUSION}

While Masterpiece Cakeshop is the place with which this article began, the destination we have ended up at is much broader. The position which has been sketched out may, or may not, be applicable to Charlie Craig and David Mullins. ${ }^{54}$ It would, however, have implications for many couples facing a similar situation. To view the marital promise to love another person as an exercise of religious or conscientious belief is to significantly alter the framing of the same-sex marriage debate. According to this perspective, it is not only the objectors to same-sex marriage for whom religious freedom or moral liberty is at stake. One major implication of this argument is that the relative burdens and benefits incurred by the respective parties must be recalibrated. Rather than it only being the aggrieved baker (or any other type of wedding vendor) who might have an interest in protecting his religious freedom, it must be recognised that the couple seeking a cake as part of their endeavour to celebrate making marital vows to one another also have such an interest. This is particularly true in relation to the couple's marriage cake, due to the fact that, as food historian William Woys Weaver notes, "the Great Cake...is a food that has become a veritable institution. A wedding without it would be a wedding without protocol, a rite without confirmation." ${ }^{55}$ Put another way,

as forms of religious belief under the U.S. Constitution's First Amendment) and Malnak v. Yogi, 592 F.2d 197 (3d Cir. 1979) (in which the Court recognized transcendental meditation as a constitutionally protected religious belief).

53 Space here unfortunately does not permit further exploration of the existential and phenomenological dimensions of the marital promise. For an extensive philosophical and theological meditation on the transcendental dimensions of the marriage "resolution", see Søren Kierkegaard, Stages on Life's Way 87-184 (Edna H. Hong \& Howard V. Hong eds \& trans., 2013).

54 For this reason, the argument sketched in this article is unlikely to provide a basis for arguing in favour of same-sex marriage per se, simply due to the plurality of ways in which people might choose to become married.

55 William Woys Weaver, Foreword, in Simon R. Charsley, Wedding Cakes and Cultural History vii (1992). 
the cultural significance of the marriage cake is such that in many cases it is not seen as accidental to the marital-vow ceremony, but rather as an essential to its completion. ${ }^{56}$ To be denied a wedding cake would therefore be to incur a burden which is comparable to that of the religious business owner.

As previous cases illustrate, ${ }^{57}$ the right to religious expression - which some scholars, owing to its placement in the U.S. Constitution, have dubbed America's "first freedom"- is often weighed by the Court as a highly important interest. In the context of a same-sex couple's pursuit of their (post-Obergefell) constitutionally protected legal marriage, as well as the anti-discrimination statutes which prohibit denial of services on the basis of sexuality, the argument here would seem to add substantial weight to the couples' case. Additionally, if Justice Gorsuch's perspective on religious freedom's importance is considered, then it is the prerogative of religious belief-exercisers (which now includes the homosexual couples pursuing marital promises) to define the meaning and significance of the cake being sought for their marriage. ${ }^{58}$

Such a shift in judicial perspective could have significant import for those seeking to champion the rights of betrothed homosexual couples. At the same time however, it may also be claimed that the opposition between the two sides is now even more intractable than it was before. With religious or conscientious beliefs potentially manifesting on both sides of the baking sales counter, it is not at all clear how the two positions can be meaningfully mediated, ${ }^{59}$ or neutrally adjudicated. It thus perhaps remains the case that in matters of religious freedom and nondiscrimination, we are incapable of having our cake and eating it too.

56 The significance of the wedding cake to the marriage ceremony which Weaver here notes arguably provides a basis for differentiating it from other marriage related services (e.g. wedding photography or flowers).

57 See, e.g., Cantwell v. Connecticut, 310 U.S. 296 (1940); Wisconsin v. Yoder, 406 U.S. 205 (1972); Church of the Lukumi Babalu Aye, Inc. v. Hialeah, 508 U.S. 520 (1993).

58 To briefly anticipate the charge that this argument risks being too broad in its implications, it should be noted that nothing here suggests that the freedom to make a marital promise of unconditional love should be indiscriminate or absolute; other considerations may still constitutionally trump the exercise of this freedom.

59 The philosophical navigation of conflicting rights, such as in this scenario, may arguably hinge upon what, exactly, the basis and rationale for these rights is conceived to be. Certain rights, it may be suggested, should be afforded greater weight because they are in some sense foundational: that is, they are more intimately connected to the ontology of, and root justification for, constitutional or human rights per se. At this theoretical level, much might therefore depend on whether a couple's pursuit of the marital promise to love one another can be said to cohere with the moral underpinnings of rights itself. This question, in turn, hinges upon what the conceptual relationships between love, justice and rights are posited to be. Space here does not allow for sufficient development of this line of inquiry. For one recent proposal which might provide a rewarding conversationpartner, see Michael Perry's defense of what he terms the Other-regarding "agapic sensibility" at the core of human rights in Michael J. Perry, A Global Political Morality 24-41 (2017); Michael J. Perry, The Morality of Human Rights, 42 Hum. Rights Q. 434 (2020). 
